\title{
User Acceptance and Motivation of E-Governance Services Based on Employees Levels of Experience in the UAE SME
}

\author{
Abdulaziz Alras hidi \\ Collage of Management and Public Administration University of La Verne, California, USA
}

\begin{abstract}
This research figure on the study of factors related to e-government acceptance and motivation in the United Arab Emirate (UAE) Smalland Mediu m Enterprises (SME). The study has been focused on the integration of motivation into the technology acceptance model (TAM) and theory of planned behavior (TPB) to wards using e-Government. An online survey was created to measure the user opinion about the e-Government ease of use, usefulness, and motivation. In this survey, we empirically validated the proposed framework by use of 130 completed questionnaires belonging to the users of e-government services offices in UAE SME. The results of data analysis by SPSS show that, accepting of services provided by e-Government services offices can be explained in terms of motivation, ease o fuse, and usefulness.
\end{abstract}

Keywords TAM, Motivation, E-Government, SME, Enterprise Services

\section{Introduction}

Electronic government (e-Government, also known as e-gov, digital government, and a certain context transformational government) refers to government's use of information technology to exchange information and services with citizens, businesses, and other arms of government[1-2]. e-Government may be applied by the legislature, judiciary, or admin istration, in order to improve internal efficiency, the delivery of public services, or processes of democratic governance. The primary delivery models are Government-to-Citizen or Govern ment-to-Custo mer (G2C), Government-to-Business (G2B) and Govern ment-to-Govern ment (G2G) \& Govern ment-to-Emp 1 oyees $(\mathrm{G} 2 \mathrm{E})[3]$.

e-Government is often thought as "online government" or "Internet-based government". Many electronic government technologies can be used in this context. Some non-internet procedures include telephone, fax, Personal Digital Assistant (PDA), Short Message Service (SMS) text messaging, Multimedia Messaging Service (MMS), wireles s networks and services,

Bluetooth, tracking systems, Radio-frequency identification (RFID), biometric identification, road traffic management and regulatory enforcement, identity cards, smart cards and other Near Field Communication (NFC)

* Corresponding author:

aalrashidi99@yahoo.com (Abdulaziz Alrashidi)

Published online at http://journal.sapub.org/economics

Copyright (C) 2012 Scientific \& Academic Publishing. All Rights Reserved applications; polling station technology (where non-online e-voting is being considered), Television (TV) and radio-based delivery of government services, email, online community facilities, newsgroups and electronic mailing lists, online chat, and instant messaging technologies[4]. There are also some technology-specific sub-categories of e-Govern ment, such as mobile government (m-government), ubiquitous government (u-government), and GIS/GPS applications for e-Government (g-government)[5].

To determine the acceptance level of individuals towards the use of e-Government services, it's requiring to look through two major problems. First, previous studies on information systems (IS) adoption and acceptance focus on business and for-profit organizations, not on governmental and public organizations. There are significant differences between private and public organizations. For example, governments are less market exposure, more legal and formal constraints, and more complex constraints for information systems. Second, although numerous studies on improving e-Government services have been proposed, us eful emp irical research is deficient. e-Government is more to online service delivery system. Behavioral issues of e-Government research are markedly more important than technological. More empirical studies on user acceptance of e-Government services are needed to assist governments in improving the effectiveness and quality of e-Government services [6-8]

e-Government may increases the convenience and accessibility of government services and information to citizens [9]. Despite the benefits of e-Government, increased government accountability to citizens, greater public access 
to information and a more efficient, cost-effective government, the success and acceptance of e-Government initiatives, such as online voting and license renewal, are conditional upon citizens' willingness to adopt this innovation[10]. In order to develop citizen-centred e-Government services that provide participants with accessible, relevant information and quality services that are more expedient than traditional 'brick and mortar' transactions, government agencies must first understand the factors that influence citizen adoption of the e-Government services.

\section{Prior Research}

A number of studies have investigated the adoption of e-Govern ment services using technology acceptance theories and models, such as the Theory of Reasoned Action (TRA)[11], the Theory of Planned Behavior (TPB)[12], the Technology Acceptance Model (TAM)[13], the Diffusion of Innovation (DOI)[14], and the Unified Theory of Acceptance and Use of Technology (UTAUT)[15]. These studies provide useful insights and implications for understanding an individual's intention of using e-Government services. They also have identified a number of factors that determine the adoption of e-Government services, such as usefulness, ease of use, perceived risk, trustworthiness, compatibility, external influence, Internet safety, interpersonal influence, relative advantage, image, and facilitating conditions (See for example[16-18]. Therefore, this study used TAM along with the TPB to formulate the degree of user acceptance along with the motivation.

A study was established by Norazah and Ramayah in[19] to investigate the effects ofe-Government services to operate in a more transparent and accountable manner of which it increases the power of the individual in relation to that of the government. They reported the success factors that use to indicate the individual attitude towards e-Government services using a theoretical model based TAM. Data relating to the constructs were collected from 200 respondents. The results demonstrated that e- Government services acceptance can be explained in terms of compatibility and attitude towards e-Government services. The setup of the e-Government services was compatible with the way users work and are more likely to adopt e-Government services owing to their familiarity with the Internet for various offic ial, personal, and recreat ional uses.

Al-Shehry et al. in[20] examined the user motivation level to use e-Government services that represents a fundamental change in the whole public sector structure, values, culture and the ways of conducting business. Their study focused on the radical change within government and in the relationship between a government and its citizens. They aimed to investigate the motivations behind the change towards e-government systems. In addition, the understanding of these motivations can help decision-makers appreciate the success and risk factors in e-government adoption. E-government characteristics therefore are discussed, and then the motivations for this change are investigated through empirical case studies from the Kingdom of Saudi Arabia. Figure 1 shows the motivation for e-Government adaptation.

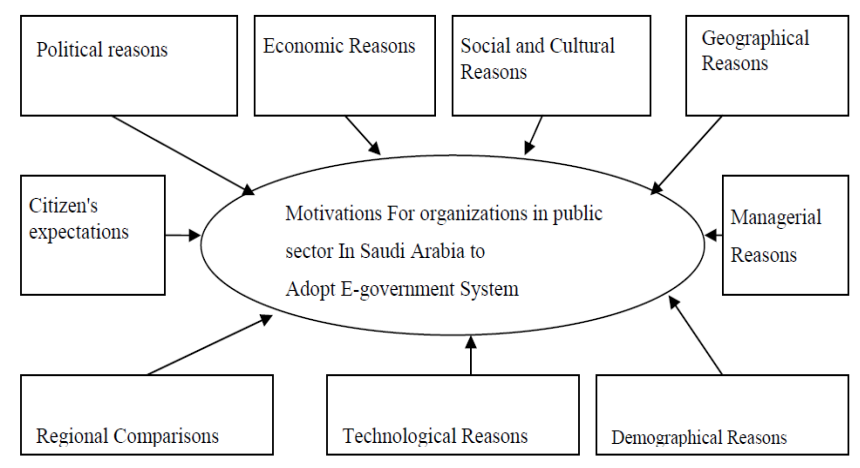

Figure 1. The Motivations for E-government Adoption

Suki et al. $\operatorname{In}[21]$ have identified the factors that determine users' acceptance of e-Government services and its causal relationships using a theoretical model based TAM. Data relating to the constructs were collected from 200 respondents in Malaysia and subjected to Structural Equation Modeling analysis. Results indicate that the important determinants of user acceptance of the e-Government services are perceived usefulness, ease of use, compatibility, interpersonal influence, external influence, self efficacy, facilitating conditions, attitude, subjective norms, perceived behavioral control, and intention to use e-Govern ment services/system.

\section{Method}

We used the online survey as a quantitative method to collect the research data. Generally, the questionnaire is a self-report questionnaire. The biggest advantage of the self-report questionnaire is that the researcher can obtain quantitative data for analysis [22].

In this study, the population refers to the entire group of postgraduate level of individuals (Employees) from different SME offices in UAE. There were 40 items included in this section that dealt with the participants' ease of use (11 items), usefulness (9 items), motivation (10 items), towards using e-Government.

\subsection{Res earch Sample}

In terms of the research sample, there are several methods of sampling that can be used to draw samples from a population.[23] categorized probability sampling techniques into five categories, simple random, systematic, stratified, cluster and multistage. A stratified sampling technique was used in this study by dividing participants into homogeneous subgroups before sampling. The sample for this study was the employees from different UAE SME offices.

\subsection{Data Analysis}


Data analysis is the process of systematically searching and arranging the research data. The data collected was processed by using Statistical Package for Social Science (SPSS) program. SPSS was used to analyze data as follows:

1. The descriptive statistics used in summing the data including means, standard deviations, and modes.

2. ANOVA test was used to determine the participants' perceived usefulness, ease of use, and motivation to use e-Government.

\section{Result}

Table 1 presents the homogeneity of variances for levels of processing differed by school among 102 participants.

Table 1. Homogeneity of Variances for Levels of Processing by School

\begin{tabular}{ccccc}
\hline & Levene Statistic & df1 & df2 & Sig. \\
\hline Context & 3.637 & 2 & 99 & .030 \\
Understanding & .603 & 2 & 99 & .549 \\
\hline
\end{tabular}

The total mean for ease of use was 18.76 (3.75 by the Likert scale) with $\mathrm{SD}=3.06$ indicating that the participants from UAE SME found the e-Government to be easy to use, as shown in Table 2. An analysis by experience level reveals the mean for ease of use for beginner employees was 18.63 with $\mathrm{SD}=1.84$, while the mean by advanced employees was 19.04 with $\mathrm{SD}=2.73$, and the mean by professional emp loyees was 4.60 with $\mathrm{SD}=1.15$. Results of the ANOVA test showed that $F(2,99)=.1702$ at $p=.188$. As $p>.05$, there is no significant difference between the respondents with respect to the ease of use by experience level.

The total mean for usefulness was 17.94 (3.58 by the Likert scale) with $\mathrm{SD}=4.36$ indicating that the participants fro m UAE SME found e-Govern ment to be useful as shown in Tab le 2. An analysis by experience level reveals the means for e-Government by beginner employees was 17.00 with $\mathrm{SD}=4.40$, while means by advanced employees participants was 18.42 with $\mathrm{SD}=4.19$, and means by professional employees was 16.06 with $\mathrm{SD}=4.82$. Results of the ANOVA test showed that $F(2,99)=.2195$ at $p=.117$. As $p>$ 0.05 , there is no significant difference between the respondents with respect to the usefulness by experience level.

Furthermore, the total mean for motivation was 17.7542 ( 3.43 by the Likert scale) with $\mathrm{SD}=4.33$ indicating that the participants found e-Government to be motivated as shown in Table 2. An analysis by employees experience level reveals the means for motivation by beginner employees was 18.0400 with $\mathrm{SD}=4.73$, while means by advanced employees was 16.4634 with $\mathrm{SD}=4.13$, and means by professionalemp loyees was 17.2321 with $\mathrm{SD}=4.33$. Results of the ANOVA test showed that $\mathrm{F}(2,99)=.2236$ at $\mathrm{p}=.134$. As $p>0.05$, there is no significant difference between the respondents with respect to the motivation by level of experience.
As $p>.05$ for all tests, the results indicate that there are no significant differences between the respondents with respect to ease of use, usefulness, and motivation by experience levels.

Table 2. Means, standard deviations and results of ANOVA tests for Ease of use, Usefulness, and motivation by experience levels

\begin{tabular}{lccccc}
\hline & $\begin{array}{c}\text { Level of } \\
\text { Experience }\end{array}$ & $\mathrm{N}$ & Mean & $\begin{array}{c}\text { Std. } \\
\text { Deviation }\end{array}$ & $\begin{array}{c}\text { Results of } \\
\text { ANOVA }\end{array}$ \\
\hline \multirow{5}{*}{ Ease of use } & Beginner & 36 & 18.6250 & 1.84 & \\
& Advanced & 78 & 19.0385 & 2.73 & $\mathrm{~F}(2,99)=.1702$ \\
& Professional & 16 & 17.5000 & 4.60 & $\mathrm{p}=.188$ \\
& Total & 130 & 18.7647 & 3.06 & \\
& Beginner & 36 & 17.0000 & 4.40 & \\
& Advanced & 78 & 18.4231 & 4.19 & $\mathrm{~F}(2,99)=.2195$ \\
& Professional & 16 & 16.0625 & 4.82 & $\mathrm{p}=.117$ \\
& Total & 130 & 17.9412 & 4.36 & \\
& Beginner & 36 & 18.0400 & 4.73 & \\
& Advanced & 78 & 16.4634 & 4.10 & $\mathrm{~F}(2,99)=.2236$ \\
& Professional & 16 & 17.2321 & 4.43 & $\mathrm{p}=.134$ \\
& Total & 130 & 17.7542 & 4.33 & \\
\hline
\end{tabular}

\section{Conclusions}

This study was conducted to exp lorer the effectiveness of e-Government services in the UAE SME. The study involved the success factors extracted from the previous researches. Ease of use, usefulness, and motivation were used to measure the effects of e-Government based on the employees' levels of experience. The overall of the evaluation found to be high enough among participants with beginner level of experience. The results revealed that there were no significant differences between the respondents with respect to usefulness, ease of use, and motivation. The findings indicate that the e-Government was acceptable and suitable by level of experience in the UAE SME.

\section{REFERENCES}

[1] R. Kumar and M. L. Best, "Impact and sustainability of e-government services in developing countries: Lessons learned from Tamil Nadu, India," The Information Society, vol. 22 , pp. 1-12, 2006.

[2] E. Eyob, "E-government: breaking the frontiers of inefficiencies in the public sector," Electronic Government, an International Journal, vol. 1, pp. 107-114, 2004.

[3] K. Layne and J. Lee, "Developing fully functional E-government: A four stage model," Government Information Quarterly, vol. 18, pp. 122-136, 2001.

[4] L. Carter and F. Bélanger, "The utilization of e-government services: citizen trust, innovation and acceptance factors," Information Systems Journal, vol. 15, pp. 5-25, 2005. 
[5] M. Horst, et al., "Perceived usefulness, personal experiences, risk perception and trust as determinants of adoption of e-government services in The Netherlands," Computers in Human Behavior, vol. 23, pp. 1838-1852, 2007.

[6] A. Alasem, "An Overview of e-Government Metadata Standards and Initiatives based on Dublin Core," Electronic Journal of e-Government, vol. 7, pp. 1-10, 2009.

[7] S. Y. Hung, et al., "Determinants of user acceptance of the e-Government services: The case of online tax filing and payment system," Government Information Quarterly, vol. 23, pp. 97-122, 2006.

[8] W. Huang, et al., "Key factors influencing the adoption of e-government in Australian public sectors," AMCIS 2002 Proceedings, p. 84, 2002.

[9] L. Carter and F. Bélanger, "The utilization of e government services: citizen trust, innovation and acceptance factors*," Information Sy stems Journal, vol. 15, pp. 5-25, 2005.

[10] D. M. West, "E - Government and the Transformation of Service Delivery and Citizen Attitudes," Public administration review, vol. 64, pp. 15-27, 2004.

[11] M. Fishbein and I. Ajzen, Belief, attitude, intention and behaviour: An introduction to theory and research: Addison-Wesley, 1975.

[12] C. J. Armitage and M. Conner, "Efficacy of the theory of planned behaviour: A meta - analy tic review," British journal of social psychology, vol. 40, pp. 471-499, 2001.

[13] V. Venkatesh and F. D. Davis, "A theoretical extension of the technology acceptance model: Four longitudinal field studies," Management science, pp. 186-204, 2000.

[14] M. Bradford and J. Florin, "Examining the role of innovation diffusion factors on the implementation success of enterprise resource planning systems," International Journal of
Accounting Information Sy stems, vol. 4, pp. 205-225, 2003.

[15] V. Venkatesh, et al., "User acceptance of information technology: Toward a unified view," MIS quarterly, pp. 425-478, 2003.

[16] L. Carter and F. Bélanger, "The utilization of e - government services: citizen trust, innovation and acceptance factors*," Information Systems Journal, vol. 15, pp. 5-25, 2005.

[17] M. Christiyanti, et al., "Analysis Technology Acceptance Model (TAM) On Application E-Banking (Empirical Study of Bank Customers In Bekasi)," Faculty of Economics, 2011.

[18] D. Gilbert, et al., "Barriers and benefits in the adoption of e-government," International Journal of Public Sector Management, vol. 17, pp. 286-301, 2004.

[19] S. Norazah and T. Ramayah, "Modelling Customer's Attitude Towards EGovernment Services," International Journal of Human and Social Sciences, vol. 6, pp. 17-23, 2011.

[20] A. Al-Shehry, et al., "The Motivations For Change Towards E-Government Adoption: Case Studies From Saudi Arabia. eGovernment Workshop'06 (eGOV06)," Brunel University, West London, UB8 3PH, 2006.

[21] N. M. Suki, et al., "User Acceptance of the E-Government Services in Malaysia: Structural Equation Modelling Approach," Interdiscip. J. Inform. Knowl. Manag, p. 5, 2010.

[22] R. Wright, "Cohen (1998) RJ Wright, M. Rodriguez and S. Cohen," Review of psychosocial stress and asthma: An integrated biopsychosocial approach, Thorax, vol. 53, pp. 1066-1074, 1998.

[23] W. Zikmund, et al., Business research methods vol. 6: Dryden Press Fort Worth, TX, 2000. 